\title{
Brazilian secularity and minorities in the biggest Catholic nation in the world
}

A Catholic country?

\section{Roberto Arriada Lorea}

\section{(2) OpenEdition}

\section{Journals}

Édition électronique

URL : http://journals.openedition.org/assr/21242

DOI : $10.4000 /$ assr. 21242

ISSN : $1777-5825$

Éditeur

Éditions de l'EHESS

Édition imprimée

Date de publication : 1 juin 2009

ISBN : 978-2-7132-2216-0

ISSN : 0335-5985

Référence électronique

Roberto Arriada Lorea, "Brazilian secularity and minorities in the biggest Catholic nation in the world », Archives de sciences sociales des religions [En ligne], 146 | avril-juin 2009, mis en ligne le 29

novembre 2013, consulté le 03 mai 2019. URL : http://journals.openedition.org/assr/21242 ; DOI

$10.4000 /$ assr. 21242 


\section{Roberto Arriada Lorea}

\section{Brazilian secularity and minorities in the biggest Catholic nation in the world}

\section{A Catholic country?}

It is common to hear that Brazil is the largest Catholic country in the world. This mistaken notion arises from some confusion about what the country is as a State and the belief of a majority of the population. Claiming that Brazil is the largest Catholic nation in the world implies disregarding $36 \%$ of the population, a group comprising 54 million non-Catholic believers and 13 million people who have no religion or are atheists. ${ }^{1}$ This data, collected through surveys, are in agreement with official demographic data, which indicate a steady shrinkage of the Catholic population in Brazil when comparing data from 2000 with data from $1991 .^{2}$ Thus, it would be better to claim that the largest Catholic population in the world lives in Brazil, a secular country.

The proposal of this article is to ponder over Brazilian secularity. To do so, I will start with a brief description of the succession of legislation which brought the Catholic Church to its prevailing position on the Brazilian religious market. Subsequently, I will look at the legal system and the main articles of the Constitution assuring the secularity of the Brazilian State. Based on the secularity assured by the law, I will present a set of judicial demands that demonstrate, to some extent, the current disputes regarding secular liberties, which can be construed as a reflection of the greater awareness among Brazilian minorities about their

1. According to data from the Datafolha Survey conducted in 2007, 64\% of Brazilians declare to be Catholic (Datafolha, 2007). According to the Brazilian Geography and Statistic Institute (IBGE), the Brazilian population in 2008 is estimated to be $186,592,388$ people (Instituto Brasileiro de Geografia e Estatística, 2008).

2. In the comparison between the two most recent censuse studies carried out by the Brazilian Geography and Statistic Institute (IBGE), it is found that the Catholic population corresponded to $83 \%$ of the population, decreasing to $73.6 \%$ in the next decade. Reversely, the number of Evangelicals grew significantly, increasing from $9 \%$ to $15.4 \%$, followed by the population without religion, whose participation increased from $4.7 \%$ to $7.4 \%$ in the period between the two censuses. The current picture is completed by $1 \%$ of Spiritualists, $0.3 \%$ of Umbandistas and Candomblé followers, and $1.8 \%$ of practicers of "other religiosities". 
right to equal treatment in religious matters. Finally, I will present a brief conclusion, in which I will attempt to show different perspectives from which one can think about Brazilian secularity.

\section{The origins of the Catholic tradition in Brazil}

Investigating the origins of the Catholic tradition in a country of continental dimensions like Brazil implies the use of a number of investigative possibilities in face of countless regional and local peculiarities. For the purpose of this article, I will adopt a line of analysis whose central axis will be the impact of legislation regulating the relationship between Church and State, favoring the Catholic hegemony in Brazil.

There were two main texts that contributed to the hegemony of the Catholic thought in the colonial period. The Philippine Ordinations of 1603 reflected the Council of Trent, adopted as law by Portugal and applied in its colonies as well.

In order to be able to evaluate the impact of this legislation on the theme of religious allegiance, we must mention, as an illustration, that Book V of the Ordinations established the crimes of heresy and apostasy, establishing the predominance of the Ecclesiastic Court for the trial of such crimes in order to subject heretics and apostates to the Holy Office Tribunal, which was in effect in Brazil until 1810 (Ordinations, 1999: 55). Book V became known for the cruelty of the penalties it imposed, which did not apply to Christians only, but extended to the entire population. An example of this social regulation by the ecclesiastical law is illustrated by the criminalization of the sexual relations between a Christian woman and an infidel. The stipulated penalty was the death, not only for the Christian woman, but for both.

In the civil sphere, the Constituições Primeiras do Arcebispado da Bahia ${ }^{3}$, of 1707 , added to the rigor of the existing criminal law, in order to shape the usage and customs of the population, and consolidate it as a Catholic society. With an eye to the consciences of future generations, Title II of the First Constitutions forced parents, teachers, masters and slave owners to teach the Christian doctrine to children, disciples, servants and slaves, establishing rigid oversight to enforce these duties by means of visitors, whose powers allowed them to forbid those not complying with such duty to teach. In this same line of thinking, completing the framework of domination, Title $\mathrm{V}$ of the 1707 ecclesiastical text stands out, which was intended to silence any opposition to the methods employed by the Catholic Church to enforce its religious doctrine in Brazil:

“TTTLE V. ON HOW LAYPEOPLE SHOULD NOT DISPUTE MATTERS OF OUR FATTH. Complying with the dispositions of the Holy Canons, we forbid under the penalty of excommunication, and ten cruzados applied by the Justice Official, and accuser, any laypeople, however

3. First Constitutions of the Archbishopric of Bahia. 
educated and literate, to dare dispute publicly or in privacy the mysteries of our Holy Faith and Christian Religion." (Constitutions, 2007: 7).

Brazil's independence from Portugal, in 1822, did not change the privileged status of the Catholic Church, as the Imperial Constitution of 1824 asserted in its $5^{\text {th }}$ article, "The Roman Apostolic Catholic Religion shall remain the Religion of the Empire. All other Religions shall be permitted with their domestic or private practice at places intended for this, without any manifestations outside the Temple."

One can consider the tolerance towards religious worship as an important legal landmark, an accomplishment in terms of freedom of conscience in comparison to the Colonial Period. Nevertheless, it would still take many years until actual freedom of worship could be achieved, since the Philippine Ordinations remained in force until 1830, when the Empire's Criminal Code was put into effect.

Only after the proclamation of the Republic, on November 15, 1889, did the Brazilian State formally separate itself from the Catholic Church by Decree. ${ }^{4}$ The Republican Constitution of 1891 was a reflection of its time, secularizing the State. Article 72 states that all individuals and religious creeds may engage in their worship practices publicly and freely; it only recognizes civil marriages; it secularizes cemeteries, handing them over to the public administration; adopts secular education in public schools; and forbids the funding of religions by the State, prohibiting any alliance or dependent relationship between Church and State.

Evidently, after four centuries of Catholic hegemony, a formal statement would not suffice for Brazil to truly transform itself into a secular State, in the sense of having its political institutions disengaged from religious ones.

The perseverance of the Catholic Church in resuming its privileged status, associated to the inability of the State to fully occupy the social spaces which had long been dominated by religious forces, allowed the successive Constitutions (1934, 1937, 1946, 1967, and 1988) to mitigate the strict separation between Church and State imposed upon with the proclamation of the Republic. The first retrocession was the re-establishment of religious education-mandatory-in public schools, a measure adopted in 1931 by President Getúlio Vargas, who had taken office through the disruption of the democratic order in 1930. Also in the Vargas era, the "collaboration of public interest" between the Church and the State was introduced into the Constitution of 1934.

4. The legal separation between the State and the Catholic Church was put into effect by Decree no. 119-A, of January 7, 1890. The institution of civil marriage followed, through Decree no. 181, of January 24, 1890. It is important to mention that the establishment of civil marriage, until then inexistent in Brazil, was the object of heated debates, notably following the first migrations of Europeans to South Brazil, entailing the demand for religious marriages between non-Catholics, which was regulated in 1863 through the Decree no. 3.069. 
In the Getúlio Vargas Government, the Catholic Church managed to resume a large share of its influence over the State. See a description of that period in the words of Mir:

"The new constitutional text was promulgated in the name of the Roman god, it acknowledged the right to religious education in public schools and forbid divorce. The Catholic hierarchy toed the line of the Vargas regime without any qualms. And public manifestations of the new political role of Catholicism emerged in the country with the national eucharistic congresses, held in the main urban centers and rallying great numbers of people, with civilian and military authorities cheerfully joining the members of the Catholic hierarchy." (Mir, 2007: 122)

Note that the strengthening of the Catholic Church with the Brazilian State goes hand in hand with periods of suppression of democracy. Gradually, the lines between the field of religion and state power were blurred. Among others, we can mention the return of legal effects to religious marriage, religious assistance in the Armed Forces, the creation of public religious holidays, and the introduction of the expression "God be praised" to Brazilian currency.

Learning about the origins of the Brazilian Catholic tradition contributes to refute the Catholic Church's recurrent argument, whereby it defends its privileges with the Brazilian State on the grounds that a majority of the population is still Catholic. ${ }^{5}$ This claim is illegitimate, as Machado clarifies:

"As Cass Sunstein says, rules and social practices cannot be justified by the social practices they brought about themselves. In his words, a legal system that has produced preferences through the unfair limitation of opportunities may hardly justify itself on the grounds of existing preferences. A constitutional order based on human dignity and on fundamental rights cannot ignore the issue of content genesis and the consequences from the social reality on the ground, particularly regarding its impact on individual and collective fundamental rights. Additionally, it must acknowledge the fact that, in promoting the discontinuance of unequal regulatory practices, it is decidedly contributing to the elimination of ingrained and systemic discriminatory attitudes and prejudices." (Machado, 2002: 154).

Accordingly, what one needs to bear in mind regarding the Brazilian case is that, as occurs in other countries colonized by the Holy See, the presence of a mostly Catholic population results from a historically constructed situation of inequality, which cannot reflect a democratic society.

\section{The citizen Constitution}

To analyze the current Federal Constitution of 1988 , we must take into account that the same reflects the end of a 20 -year-long military dictatorship

5. Projections have started to be done about when the Catholic population will cease to be a majority in Brazil. This was the theme of the opening conference in the XIV Symposium on Religious Alternatives in Latin America, held in Buenos Aires, in September 2007, which was assigned to Reginaldo Prandi, from the University of São Paulo (USP). 
legitimated by the Catholic Church, a period (1964-1985) in which democratic liberties were suppressed. ${ }^{6}$ The acknowledgement by the military of the services rendered by the Catholic Church did not take too long to be expressed: once the democratic government of João Goulart was toppled, General Castello Branco was sworn in as president and proclaimed Nossa Senhora Aparecida (Our Lady Who Appeared) the "commander in chief" patron saint of Brazil.

The country's re-democratization led to the National Constitutional Assembly, which drafted the text now known as the "Citizen Constitution". Promulgated in 1988 "under the protection of God", the new text maintains the separation between the Church and the Brazilian State. Below I transcribe the main articles in the Constitution that address the topic of religion.

$5^{\text {th }}$ Article - All are equal under the law, without any sort of distinction, Brazilians and foreigners residing in the Country are assured the right to life, freedom, equality, safety and property, on the following terms:

(...)

$\mathrm{VI}$ - the freedom of conscience and creed is inviolable, the free exercise of religious worship is assured and the protection of places for religious worship and respective liturgies is guaranteed by law;

VII - the rendering of religious assistance in civilian and military entities of collective internment is assured by law;

VIII - nobody shall be stripped of their rights due to their religious creed or philosophic or political conviction, save if they invoke those to exempt themselves from a legal obligation imposed upon all and refuse to render an alternative service stipulated by law;

$19^{\text {th }}$ Article - The Central Government, States and Federal District, and Municipalities are prohibited to:

I - establish religious creeds or churches, subsidize them, constrain their operation, or maintain with them or their representatives dependence or alliance relations, save, according to the law, collaboration of public interest;

Article 210. Minimum contents will be established for elementary education so as to ensure common basic formation and respect for national and regional cultural and artistic values.

$\$ 1^{\text {st }}$ - Religious education, for which the enrollment shall be optional, will constitute a subject present in the regular schedule of public elementary schools.

We can start the analysis by claiming that the allusion to God, present in the preamble to the constitutional text, does not yield any legal effect, as has already been decided by the Federal Supreme Court.

6. Although there were some Catholic leaders who, far later, contributed to the redemocratization of the country, the fact is that the National Conference of Bishops of Brazil, CNBB, participated in the military coup in 1964, promoting the movement "March of the Family with God for Freedom" and, after the coup d'etat, it issued a public notice supporting the military: "Rendering thanks unto God, who answered the prayers from millions of Brazilians and set us free from the Communist danger, we thank the military who, severely risking their lives, rose on behalf of the ultimate interests of the nation, and we are grateful to all of those who contributed to freeing us from the looming abysm" (Löwy, 1997). 
Still on the legal relevance of the allusion to God present in the preamble, it is necessary to stress that the matter has already been the object of a dispute at the Supreme Federal Court (STF). In a plenary trial, which addressed exactly the question of the reference to God's protection present in the preamble to the 1988 Federal Constitution, the STF ministers arrived at a unanimous conclusion about the legal irrelevance of the preamble.

In face of a direct appeal of unconstitutionality, which intended to force the allusion to God's protection present in the Federal Constitution into State Constitutions, the Supreme Federal Court left no doubts whatsoever about the secularity of the Brazilian State:

"This invocation, however, placed in the preamble to the Federal Constitution simply reflects a deistic and religious feeling, which is not inscribed in the Constitution, especially because the Brazilian State is secular, the Constitution sanctions the freedom of conscience and creed (Federal Constitution, $5^{\text {th }}$ Article), assuring that no one shall be striped of their rights for the reason of religious creed or philosophical or political conviction (Federal Constitution, $5^{\text {th }}$ Article, VIII).

The Constitution belongs to everyone, not distinguishing between deists, agnostics or atheists.

The reference to or invocation of the protection of God has no greater meaning, so much so that the Constitutions of the States in which a majority of the population practices theism, do not contain this reference. I mention, for example, the Constitutions of the United States of America, France, Italy, Portugal, and Spain." (Supreme Federal Court, Direct Appeal of Unconstitutionality 2076-5, Acre. Reporter Min. Carlos Veloso, 08/15/2002)

In the judgment it was established that "the preamble is not a juridical norm", given that "it is not in the scope of Law, but in the domain of Politics, reflecting the ideological position of the legislator." In his vote, the justice delivering the opinion, mentioning the constitutionalist from the University of Lisbon, Jorge Miranda, asserts: "The preamble does not yield rights and duties", as a result "there is no unconstitutionality in violating the preamble". (Supreme Federal Court, Direct Appeal of Unconstitutionality 2076-5, Acre. Reporter Minister Carlos Veloso, 08/15/2002).

On the occasion, the Minister Sepúlveda Pertence, referring to the preamble, stressed his vote:

"This phrase 'under the protection of God' is not a juridical norm, since one would not intend to create an obligation for the deity invoked." (Supreme Federal Court, Direct Appeal of Unconstitutionality 2076-5, Acre. Reporter Minister Carlos Veloso, 08/15/2002).

Note that the interpretation that attempts to provide constitutional power to the invocation to God present in the Constitution preamble is wrong and reinforces the pressing need for further secularity studies, a subject that should be included in the curriculum of Law courses. 
However, in terms of laicity, it must be regarded as a retrocession, especially as compared to the first Republican Constitution, which did not include a similar reference. Likewise, the religious assistance in the Armed Forces and religious education in public schools, if taken as indicators of laicity, mean a retrocession compared to the terms of the 1891 Constitution. However, if we consider that even in the Republic, with Vargas, religious education was mandatory, we concede that the optional enrollment-theoretically-exonerates children from attending religious education classes.

However, it would be a mistake to gauge laicity exclusively through its normative aspect, when there are a number of other indicators to consider. Nevertheless, it is imperative to recognize that this permissiveness in the constitutional text tends to contribute to a greater influence of religious institutions on the State.

When we think about the guaranty of secular liberties secured in the 1988 Constitution, we must take into account an important victory of the democratic forces over the religious camp. During the procedures in the National Constitutional Assembly, the protection of life since conception was proposed. This proposal was rejected by the assembly members in a significant victory for the democratic forces. Had it been different, the Constitution would have imposed upon the entire population a certain view-religious or philosophic-on what the beginning of life is, neglecting the diversity of views that exist in Brazilian society.

\section{The breach of secular liberties}

Analyzing the trajectory of secularism in the country, we can assert that there has been a broadening-albeit discontinued-of secular liberties. The democratization of the religious market is reflected in the religious diversity present nowadays in Brazil. If until the $18^{\text {th }}$ and $19^{\text {th }}$ centuries the Catholic Church was virtually the only protagonist in religious matters, in the $21^{\text {st }}$ century other social actors have emerged in the field of religion. However, it does not suffice to mention the increasing secularization, since this analysis would be quite incomplete if it failed to point out how much remains to be done in order to guarantee effectiveness to the secularity assured in the Constitution.

Although it is not the object of this paper to exhaustively map the breaches of secular liberties taking place nowadays in Brazil, it is useful to mention, albeit superficially, some situations illustrative of the current stage of Brazilian democracy regarding the protection of secular liberties. With this purpose, I will initially analyze some questions relative to the Executive and Legislative Branches. Finally, I will examine a few legal demands and the respective solutions presented by the Judiciary Branch. 
Common to the three branches of the Republic, we can say in advance, is the presence of religious symbols-namely, crucifixes-ornamenting public facilities. In hospitals, schools, courts, police stations, one comes across the widespread use of religious symbols at State offices. Specifically regarding the courts, it is worth mentioning the indignation expressed by Theodoro Maranhão, who in 1927 rose against what he called "the lack of civic awareness by judges" who overlooked the continuation-in some cases the placement-of religious symbols at courts. The situation lingers on and even in buildings recently inaugurated such symbols are occasionally placed.

Recently, the topic regained visibility and a campaign was organized for the removal of religious symbols. Called upon to express an opinion, the National Council of Justice (CNJ) did not take any measures. ${ }^{7}$ On the contrary, it claimed that the presence of religious symbols, as occurs at the highest court in the country ${ }^{8}$, does not violate the principle of Church-State separation. The exception was the single vote by the justice delivering the opinion, Paulo Lobo, who recognized that the display of religious symbols at courts is in breach of the State's laicity.

In the domain of the Executive Branch, we must mention the subsidization of religious activities in various forms. The state funding of pastoral campaigns organized by the Catholic Church stands out. The Ministry of Health, for instance, in 2007 donated 32.4 million reais to the Child Pastoral. ${ }^{9}$ Replacing the State in attending to needy populations, the pastoral's efforts captivate millions of people, gaining political strength and, eventually, employing its political prestige to influence the powers that be. The message sent to President Lula upon his second election is very telling of this political game:

"We take the liberty to remind Your Excellency that we took great pains in the electoral process to offer Christians and people of good will criteria for your vote. ${ }^{10}$

(...) If we could give an actual suggestion, we would draw special attention to the services of the Ministries of Health and Education, in which the great principles at the service of life, family and people's formation are put in practice." 11

While several pastorals engage in some sort of material effort aiming at the population's well-being, which might mitigate the distortion characterized by

7. Agency responsible for external control over the Judiciary Branch.

8. Supreme Federal Court, whose courtroom displays a crucifix.

9. Roughly 19 million US\$. Note that this amount corresponds exclusively to the agreement between CNBB and the Ministry of Health, which had an impact on the press. To calculate the amounts annually passed by the Brazilian State directly to the Catholic Church, it would be necessary to verify how many other public, federal, state and municipal entities fund different campaigns of the Catholic Church.

10. Although it is not the aim of the present paper, it is worth mentioning the explicit admission by CNBB of its electoral activity, despite the prohibition by the Electoral Justice that the campaign be held at places of worship. The topic, to be dealt with timely, was the object of several decisions by the Electoral Justice.

11. Text available from: http://www.cnbb.org.br/index.php?op=noticia\&subop=13182 
the fact that the State subsidizes evangelizing missions, the same does not occur in cases of direct subsidies to religious worship.

The performance of religious worship inside public facilities of the three branches of the Republic is a pervasive practice in the Brazilian public service. That points towards the need for raising the awareness of the State's political agents about their obligations regarding the freedom of conscience and creed of their subordinates, since these liberties must be respected as assured by the Federal Constitution.

Time and again, it is alleged that religious practices in public locations are supported by the possibility of cooperation provided in the $19^{\text {th }}$ article, I, of the Federal Constitution. The lesson from the constitutionalist Jose Afonso da Silva on the juridical dimension of the State-Church separation leaves no doubt as to the unconstitutionality in the performance of religious worship at public facilities, a conclusion that can be drawn from different perspectives:

"Pontes de Miranda clarified well the meaning of several prescriptions centered on the verbs in the disposition: 'establishing religious worship is in a broad sense: starting religions or sects, or building churches or any places for religious practice or propaganda. Subsidizing religious worship means contributing, with money or other assets from the state entity, to the performance of a religious activity.

(...)

But it is difficult to define the degree of collaboration of public interest allowed in the disposition proviso, according to the law. The law, therefore, is what will shape the collaboration. It is obvious that it cannot occur in the religious field. Furthermore, the collaboration must be general lest to discriminate against different religions". (Silva, 1991: 223)

The analysis is accurate; pointing out that the ones holding public offices should have discretion in the use of governmental facilities to satisfy personal creeds, which, albeit respectable, do not justify the undue use of the State to promote their religion.

Another recent example was the pope Ratzinger's visit to the city of São Paulo, when both the state and the municipality spent millions of reais to build the stage which would be used for the mass. However, the agencies responsible for inspecting public expenses have done nothing so far to hold the public administrators responsible for their attitudes violating secular liberties.

Although symbolizing the close relation of the Executive Branch with religious organizations, the economic aspect is not the most relevant for an analysis of secularism. In the Legislative Branch we can also find a direct influence of religious values on the contemplation of bills, of which the result tends to have an impact on the entire population.

In the Brazilian case, the political action of religious leaders is notable in view of the performance of Evangelical and Catholic parliamentary blocs. Taking action through political parties, parliamentary fronts are organized in order to 
defend their respective religious creeds. In the debates at the National Congress it has become commonplace to hear congressmen stating that the Bible is their "Constitution", trumpeting their political and religious identities.

An example of this attitude can be seen in an interview granted by congressman Henrique Afonso (PT, state of Acre), while supporting a bill he had written, known as "rape aid". The bill forbids abortion in the hypotheses nowadays admitted in Brazil-pregnancy resulting from rape or life-threatening pregnancyproposing, in turn, that the State pay a monthly stipend in order to encourage women to keep their child. Questioned about the laicity of his bill, the Congressman replied:

"Abortion, for us, Evangelicals, is an act against life in all cases, it does not matter if the woman is at risk or was raped. This issue about a secular State has been debated to a great extent, there are those who tell me I should not legislate as a Christian, but that's what I believe and I do what God commands, I cannot conceive of separating the two things." (Comissão de Cidadania e Reprodução, 2007)

Another example, also related to sexual rights, was the political pact made during the elections for the state government of Rio de Janeiro, in 2006. On the occasion, defeated in the first round of the election, candidate Marcelo Crivella (a bishop on leave from the Universal Church of the Kingdom of God) conditioned his support to Sérgio Cabral in the run-offs on his removal from the National Congress of his proposal for a constitutional amendment regulating stable same-sex unions. The political arrangement was largely exposed in the mass media. Senator Crivella was quoted as saying about this issue:

"Sérgio Cabral accepted my argument. This is a universal principle of both the Catholic and the Evangelical Church, which are a majority in Rio. I asked him to review his stance, and he did so. He signed a petition withdrawing the bill, and I found this an important gesture."

Apart from political arrangements at election time and also in legislative sessions, when bills are in hand, political stances based on religious values are expressed. In the commission that analyzed a bill establishing same-sex civil partnership, congressman Jorge Wilson (PPB-Rio de Janeiro) stated:

"I would just like to say that our subject is directly connected to religion, and I want to make mine the words from the noble congressman Salvador Zimbaldi, when he says there is only one holy book, the Holy Bible-a saintly book, even because it was written by men inspired by God." (Mello, 2005: 110)

In the same line of argumentation, Congressman Philemon Rodrigues (PTBMinas Gerais) expressed his view at the Commission session, identifying his opposition to the approval of said bill:

"Let me now say that half a dozen advocates of homosexuals in this country have no right to intend to impose upon the Brazilian Nation something that hurts the honor and morals of this Catholic Nation, which holds Christian principles." (Mello, 2005, 108) 
These are attitudes which violate the freedom of conscience stipulated in the Constitution and attempt to impose a single view on the entire population. Legislative initiatives motivated by religious values have led, notably in cities in the countryside of the State of São Paulo, to the approval of municipal laws prohibiting the distribution of the morning-after pill at health centers in that city. ${ }^{12}$ As a result, the Judiciary Branch, called upon to decide on the constitutionality of these laws, has declared them unconstitutional, voiding them. However, there are other cases of cities enacting similar laws. These prohibitive laws rely on the support of $\mathrm{CNBB}$, which alleges that the morning-after pill is an abortive substance, a claim refuted by the scientific community.

Also in the legislative field, a law enacted in Entre-Ijuís, a small town located in the southernmost region of Brazil, was given a great deal of media attention. This law established daily obligatory Bible reading in that town's public schools. The Court of Justice of Rio Grande do Sul, acknowledging that the law violated the Constitution, voided it.

To conclude this brief summary on the legislative field, it is worth mentioning a significant bill currently making the rounds, which proposes to assure Reproductive Rights and decriminalize abortion in Brazil. Undoubtedly, it is a bill that has mobilized progressive forces, such as feminists, healthcare providers and a part of jurists. However, so far the conservative forces have shown themselves to be superior. Under the coordination of the religious bloc (Catholic and Evangelical) the bill has been prevented from going forward. Worse yet, they have created the impression that, should the bill go to vote this year (an election year), it would be rejected at the National Congress.

The Judiciary has been called upon to guarantee equal religious treatment in all fields of Law. Ranging from lawsuits in the Court of Labor Justice in Santa Catarina, where an employee felt constrained to pray and use religious symbols at his/her workplace, to Administrative Law, in which a public competition for military chaplain in the Federal District was made void, as the edict admitted Catholic or Evangelical candidates only, and to Electoral Law, when two pastors were arrested for campaigning for candidates at a temple in Minas Gerais, a situation forbidden by the electoral legislation, even though the Catholic Church was allowed to do campaign work at its churches in Rio de Janeiro in the 2006 elections.

Recently, in the state of Rio Grande do Sul, a new Public Security Secretary took office. On his first working day, as amply published in the media, a new weapon against crime emerged: faith.

12. In Brazil, there exists the Unified Health System (SUS), which provides universal healthcare, with distribution of several medications free of cost. Health centers take part in this system. 
The press informed the public that the new director of the Public Security Department of Rio Grande do Sul, in accordance to his practice at other offices in which he had worked, intended to pray along with his subordinates. According to the press, the new secretary would be steering the Security Department to "a practice already disseminated at the Federal Police. Every Monday, for five minutes, the workers get together to listen to a biblical citation and pray silently. To conclude, everyone holds hands and says the Lord's Prayer." 13

One can argue that nobody is being forced to participate in the prayers at the workplace. However, the question is not that simple. It seems evident that the refusal of civil servants to attend the religious function causes them some embarrassment, starting with the fact that they will become a focus of attention in view of their religious allegiance (or lack thereof), whose confidentiality is assured by the $5^{\text {th }}$ article, VI, of the Federal Constitution.

In this case in particular, the journalistic story, published in a major newspaper, showed the photo of the director and his subordinates praying together with a pastor. Since it was the first day of the new director, how should the servants react? Would they feel sure that not attending the religious function would not cause them any functional harm? It is possible, but it is also reasonable to think that civil servants might feel embarrassed to go against the will of the newly sworn director.

In transforming the space of the Public Security Department into a place of worship, the Security Secretary, either consciously or not, results in the religious harassment of civil servants, given his rank (the director) in relation to the civil servants allocated at the Security Department (their subordinates). ${ }^{14}$

With respect to this case at the Security Department of Rio Grande do Sul, it is necessary to understand that a religious practice-all of them equally respectable-is not suitable for the workplace and must be reserved for a time and place other than those in which official duties are performed.

\section{Brazilian laicity}

In May 2007, the pope's visit mobilized a million people in São Paulo, where, in the next month, three million people would take the streets on the Gay Parade. The same number participated in the "March with Jesus", organized by Evangelicals in the previous week. These events, to some extent, reflect the diversity present in Brazilian Society.

13. Voir note 1.

14. The story was published in Época magazine, issue no. 355, of March 7, 2005. The data and research methodology can be found online, available from http://www.catolicasonline.org.br. 
The decline in religious influence over Brazilian society can be calculated from different perspectives. Parallel to the cases of momentary retrocession previously mentioned, we can list a number of democratic advances, which together leave no doubt about the decline in the religious influence over the life of the Brazilian family, starting with the secularization of marriage, removing it from the grip of religion, and continuing with the enactment of the divorce law, in 1977. As regards family relations, the jurisprudence of the Court of Justice of Rio Grande do Sul stands out, with its pioneering decisions that have ensured the acknowledgment of legal effects in same-sex unions, as well as the adoption of children by gay or lesbian couples.

Also in the field of reproductive rights, the weakness of religious groups in making its world view prevail is perceivable. The liberation of customs in relation to the influence of religion has become evident if we consider that until 1979 advertising the contraceptive pill was a penal infraction, but today the State distributes the morning-after pill free of cost and prepares the distribution of condoms in schools.

Even in issues central to the religious doctrine, as is the case of abortion, the Supreme Federal Court occasionally imposes defeats on religious conservatism, as when it authorized the discontinuance of pregnancy in case of fetal malformation incompatible with life, innovating in relation to the two hypotheses stipulated in the Criminal Code. Currently, the question still awaits a final decision.

However, while it is true that religious conservatism is not strong enough to hamper the democratic achievements in Brazil, we must admit it still has enough strength to delay-for a long time-the implementation of Human Rights, especially those associated to sexual and reproductive rights.

The prospect of an independent Supreme Federal Court able to ensure human dignity on the basis of democratic values, such as freedom and equality, does not satisfy the interests of certain religious groups and brings about reactions that can influence the course of democracy. The latest appointment of a minister to take part in the Supreme Federal Court (the seventh appointment by President Lula in a total of eleven members), according to the press, had the direct intervention of the Holy See. Under the title "Choice of Menezes Direito had support from Vatican representative in the country", the story lays bare the successful behind the scenes pressure exerted by the apostolic nuncio on ministers of the Lula Administration.

Still regarding the Supreme Federal Court, currently Brazilian society in general and scientific in particular, awaits with great expectation the judgment of a matter the Public Prosecution Office took to court to forbid research on embryonic stem cells in the country. In the judgment session, after the votes of the justice that delivers the opinion and the chair of the court, both deciding in favor 
of permitting the research, minister Menezes Direito asked to take a look at the documents, postponing the decision.

While on its own behalf the Catholic Church manages to preserve its ability of influencing rulers, legislatives and judges, it has suffered an increasing loss of legitimacy to speak on behalf of its followers, a completely unsuitable pretension, since the institution does not admit any democratic mechanism of popular representation. The results from a recent survey on the behavior of the Brazilian Catholic population reinforce the absence of representativeness of the Catholic hierarchy to speak on behalf of its followers, revealing a lay attitude in most Brazilian Catholics.

Asked if legislators and judges should make decisions on the basis of the diversity of opinions existent in the country or based on the teachings of the Catholic Church, $86 \%$ of Catholics answered that the decisions should be in accordance with the existent diversity, and only $10 \%$ of Catholics said that decisions should be based on the teachings of the Catholic Church.

In the topic abortion, a huge gap is found between the Catholic doctrine and the views of its followers. Among Brazilian Catholics, $70 \%$ agree that abortion can be carried out in specific cases, and when asked if public health services should perform abortions in the cases stipulated by law, $78 \%$ answered favorably. Concerning the use of contraceptives, $86 \%$ of Catholics think these may be used by a good Catholic.

Additionally, six out of ten Catholics describe themselves as "not very practicing or not practicing at all". The rate of non-practicing Catholics rises to $80 \%$, if we use other sources (Mir, 2007: 67).

The very fact of a weekly magazine publishing a story under the title "Ibope reveals conflict between followers and orientations of the Catholic Church" is significant itself. The public in general was being informed of a study ordered from Ibope (a well-known opinion poll institute) by an NGO called Catholic Women for the Right to Decide.

The repercussion of the pope's visit to Brazil in 2007 seems to have been amply unfavorable to the interests of the Catholic Church. Democratic awareness has increased, the debate about secularism has become deeper, the Brazilian State refused the agreement proposed by the Vatican, and all of this was widely covered by the mass media.

This episode, in isolation, does not keep the tension always present between public authorities and the religious forces away. This tension is also reflected in the attitude of the President of the Republic, who, in different political conjunctures, adopts different standpoints regarding topics which are known to be on the agenda of religious institutions, most notably the Catholic Church. This ambiguity in the Government is evidenced when we compare two addresses by 
President Lula on the topic of abortion, which took place in quite different contexts.

The first one is a message sent by President Lula to the Catholic Church upon the 43rd CNBB General Assembly, in August 2005. The political moment encompassed two quite distinct situations. On the one hand, the Tripartite Commission set up by the Government to deal with the abortion issue, after ten months of work, had arrived at the conclusion that a bill should be sent to Congress proposing the decriminalization of abortion in the country. On the other, there was the corruption scandal known as the "mensalão", which had reached the highest echelons of the PT (Workers Party) Government, involving individuals who were very close to President Lula himself.

In this context, a message was sent by the President, whose content signaled the negotiation of a bill about abortion, a bill which the President was willing to renounce in exchange for the political support from CNBB to solve the corruption crisis that had stained the Government's credibility.

"In this sense, due to my identification with the ethic values of the Gospel and due to the faith I received from my mother, I want to reassure my position in defense of life in each and every aspect and in all of its range. The debates that Brazilian society is carrying out, in its cultural and religious plurality, are followed and encouraged by our government, which, however, will not take any initiative that goes against the Christian principles, as I expressly mentioned when I had the honor to receive the CNBB Leadership at Palácio do Planalto.”

Here, President Lula was giving up on an initiative from his own Government, disregarding the results of 10-months of work done by the Commission set up by the Government, which recommended the decriminalization of abortion in the country.

Less than two years later, once the "mensalão" crisis had been overcome, and already with a second presidential mandate and polls showing his high popularity, the speech changed. In an address telecast nationwide, in May 2007, President Lula says that despite being personally against abortion, the issue must be dealt with as a health public issue, endorsing José Temporão's standpoint, the first Minister of Health to publicly defend the decriminalization of abortion in Brazil.

This presidential address took place shortly after the Pope's visit, during which President Lula refused to sign an agreement, which has been coveted by the Vatican for a long time. As a matter of fact, President Lula imposed a significant defeat on the interests of the Catholic Church, refusing to sign the agreement and reassuring that the Brazilian State is secular. Thus, the Pope's expectations to formalize the agreement in Brazilian territory were frustrated during his visit to the largest Catholic population in the world.

It would not be an overstatement to say that the refusal of the Brazilian State to sign the agreement portrays the level of secularity present today in Brazilian 
Society. The topic, which until then had been handled discretely by the Holy See with Brazilian diplomats, gained sudden visibility, with broad repercussion in the mass media. Among others, the newspaper Folha de São Paulo, one of the most influential in the country, published a striking editorial denouncing the "secret agreement" proposed by the Catholic Church and praising the refusal by the Brazilian Government to kowtow to the Vatican's interests.

However, on November 13, 2008, when President Lula was visiting the Vatican, signed the agreement-whilst the Nation does not know the conditions of this term. The agreement still has to be approved by the National Congress.

Though the Executive kept as quiet as possible regarding the procedure to approve the agreement with the Holy See, the channels in the Legislative Power are much more visible. Critiques have surfaced, especially from representatives linked to the evangelical field, who are taking a stand in speeches made in Congress. The agreement has also met resistance within the juridical field. A "ação popular" (popular demand) was filed, on February 2009, against the agreement in the Federal Court of Guarulhos (São Paulo). Strictly in the religious domain, a reaction has begun, first announced by the Episcopal Council of the Methodist Church, who has released a public statement condemning the agreement with the Holy See.

We must now observe if the debate will go any further, and if a larger part of Brazilian society will become acquainted with the terms of this agreement, having their say. After all, this agreement definitely sets unequal treatment among the diverse and numerous religions in Brazil, once no other may hope to be recognized by means of an international treaty.

\section{Roberto Arriada LOREA Universidade Federal do Rio Grande do Sul - UFRGS r.lorea@gmail.com}

\section{Bibliographical References}

Comissaão de Cidadania e Reprodução (CCR), [Cited June 2008] Available from: http:// www.ccr.org.br/a_noticias_detalhes.asp?cod_noticias $=2055$.

Datafolha [Cited June 2008] Available from: http://datafolha.folha.uol.com.br/po/ dossies_index.shtml.

Estado de São Paulo, Edition December 13, 2007. [Cited June 2008]. Available from: http://www.estadao.com.br/estadaodehoje/20071213/not_imp95241,0.php.

Instituto Brasileiro de Geografia e Estatística (IBGE). Available from: http://www. ibge.gov.br/7a12/conhecer_brasil/default.php?id_tema_menu=2\&id_tema_submenu=5. Lara Hunold Silvia, 1999, Ordenações Filipinas, Livro V. São Paulo, Companhia das Letras. LöWy Michaël, 1997, "L’Église en Amérique Latine : le cas brésilien”, in Michel P., (org.), Religion et Démocratie. Nouveaux enjeux, nouvelles approches, (Tradução de C. B. Muller, revisão de E. Zambrano) Paris, Albin Michel, pp. 362-364. 
MACHADO Jonatas, 2002, "A liberdade religiosa na perspectiva dos direitos fundamentais", Revista Portuguesa de Ciência das Religiões, 1, pp. 149-154.

Mello Luiz, 2005, Novas Famílias. Conjugalidade homossexual no Brasil contemporâneo, Rio de Janeiro, Garamond.

Mir Luís, 2007, Partido de Deus. Fé, Poder e Política, São Paulo, Alaúde.

Senado Federal, 2007, Constituições Primeiras do Arcebispado da Bahia (1707), Brasília, Senado Federal.

\section{Résumé}

Cet article propose une réflexion sur la façon dont les minorités vivent sous les pressions (qu'elles soient privées ou qu'elles proviennent des acteurs politiques, c'està-dire les représentants des pouvoirs exécutif, législatif mais aussi judiciaire) qui tendent à imposer la religion majoritaire comme une religion "naturelle " (et une morale "naturelle») à tous les Brésiliens. À partir d'une analyse de comportements d'agents de l'État, de discours politiques, d'actes présidentiels, ainsi que par l'étude de décisions jurisprudentielles traduisant une réaction à cette pression sociale, nous pouvons penser qu'émerge une revendication populaire allant dans le sens d'une meilleure protection des libertés lä̈ques.

Mots-clés : Brésil, religion, laïcité, minorités, libertés laïques.

\section{Abstract}

This article proposes to reflect on the way minorities can survive under the pressure exerted on them in private, but more importantly in the public realm (executive, legislative and judicial powers), in order to force them to accept the major religion and ethics as "natural" ones for Brazilians. By examining the way the agents of the State act (political speeches, presidential actions...) and by looking at a few judicial decisions which show the existence of people's reactions to this social pressure, we will be able to demonstrate that people start reacting, asking for more secular liberties.

Key words: Brazil, religion, secularity, minorities, secular liberties.

\section{Resumen}

El propósito de este texto es reflexionar acerca de la forma en que las minorías subsisten ante la presión a la que se ven sometidas (en el ámbito de lo privado, pero en particular por parte de los actores politicos del Estado - el gobierno, el poder legislativo y los jueces, por ejemplo) para aceptar la religión mayoritaria como religión (y como moral) "natural" de los brasileños. A través del análisis de las actitudes de los actores del Estado, de algunos discursos de actores politicos, de actos presidenciales, así como de algunas decisiones del poder judicial que indican la existencia de reacciones a esta presión social, podemos pensar que la gente comienza a reaccionar pidiendo mayores libertades seculares.

Palabras clave: Brasil, religión, laicidad, minorías, libertades seculares. 